\title{
Extraskeletal effects of vitamin D
}

Correspondence: M Mesús Gómez de Tejada Romero - Departamento de Medicina (Facultad de Medicina) Universidad de Sevilla - Avda. Dr. Fedriani, s/n - 41009 Sevilla (Spain)

e-mail: mjgtr@us.es

\section{Introduction}

Since it was discovered by McCollum in 1922 how vitamin D was involved in bone mineralisation and was responsible for rickets ${ }^{1}$, much new knowledge has come to light. From being a vitamin it has become considered to be a hormone ${ }^{2}$, and with parathormone and calcitonin makes up the calciotropic hormone group. Its important role in the homeostasis of calcium and its direct action on bone tissue have made it the object of continual research in the study of mineral metabolism.

However, receptors for vitamin D (VDR) have been detected in almost all human tissues, and its capacity to regulate the expression of numerous genes has been discovered ${ }^{3}$. A randomised double blind clinical trial, recently published and carried out in 6 subjects over the winter to see the effects of vitamin D supplements over 2 months on gene expression found that at the start of the study there was a significant difference in the expression of 66 genes between subjects with vitamin D deficiency $(<20 \mathrm{ng} / \mathrm{mL})$ and those with initial levels $>20 \mathrm{ng} / \mathrm{ml}$. After 2 months with vitamin D supplements the expression of these 66 genes was similar in both groups. Furthermore, 17 genes regulated by vitamin $\mathrm{D}$ were identified as new candidates for the response to vitamin $\mathrm{D}$, which have been shown to be important for the regulation of gene transcription, immune function, response to stress and DNA repair ${ }^{4}$.

This suggests that vitamin D has a hormonal effect beyond the bone, and it is gradually being conceded that vitamin $\mathrm{D}$ has a significant role in general human physiology $y^{5,6}$.

Numerous studies have been carried out over the years in order to provide evidence of these actions outside the bone, the most significant being those which take place in the muscle, in cancers, in glucose metabolism and the immune system, which are those which we analyse in this review.

\section{Vitamin D and muscle activity}

The intervention of vitamin D in muscle function has been known for many years and has been widely studied. It has long been observed that a deficiency in vitamin D leads to myopathy characterised by proximal muscular weakness and atrophy $^{7}$, and the presence of VDR in the muscle tissue of the skeleton has been evidenced in various studies ${ }^{8-10}$, with a decrease in these receptors being observed with age ${ }^{11}$.

Vitamin D regulates muscle development and contractility, and this occurs though genomic actions, stimulating the proliferation of muscle cells and their differentiation through transcription, mediated by nuclear-specific receptors, of genes which express an increase in the synthesis of cell DNA, followed by the induction of specific muscular proteins (proteins which bond to calcium and myosin). But it also exerts non-genomic actions, interacting with the receptor specific to the muscle cell membrane, which then brings about the stimulation of adenyl cyclase and the phospholipases C, D and A2, and the action of the intracellular signalling pathways, such as the MAPK (Mitogen-activated protein kinase) cascade, which finally acts on the DNA inducing cell divi$\operatorname{sion}^{12,13}$. In a recently-published study the authors observed that mice recently born of vitamin D deficient mothers had smaller muscles cells than those whose mothers had sufficient levels ${ }^{14}$.

However, it should be said that the existence of VDR in muscle cells is questioned by some authors. In a study carried out by Wang et al., the researchers were unable to detect VDR in mouse muscle cells and observed that the antibodies use to detect the VDRs are not specific to those receptors, which could explain the possibly false positive results in earlier studies. The authors concluded that the effect that vitamin $\mathrm{D}$ has on the muscle should be indirect ${ }^{15}$. However, some authors consider that these findings may be due to differences 
in experimental conditions and the possible existence of the close bonding of the VDR with the specific hormonal response element of the DNA when coupled with vitamin $\mathrm{D}^{16}$. In any case, a small presence of VDR in the muscle may be sufficient to allow the action of vitamin $\mathrm{D}$ in these cells. Another possibility is that there may be differences in the expression of the VDR in the muscle of different species and over the different stages of muscle differentiation ${ }^{17}$. Lastly, some researchers have suggested that, apart from VDR specifically, it is possible that other cytoplasmic receptors (such as the steroids, given their molecular similarity) may be responsible for the rapid actions of the vitamin $\mathrm{D}$ metabolites in the muscle ${ }^{18}$.

On this basis, it is easy to understand that vitamin $\mathrm{D}$ takes a significant role in muscle activity ${ }^{19}$. As we indicated at the start, various studies have already for some time been demonstrating that a deficit in vitamin $\mathrm{D}$ is associated with diffuse myalgia, muscle weakness ${ }^{20,21}$ and sarcopenia, all caused by muscular atrophy, principally of type II muscle fibres, and affecting above all the proximal musculature ${ }^{22,23}$. To understand the relationship between levels of vitamin D and risk of falls and muscle weakness, Stewart et al. carried out a study in 242 healthy postmenopausal women. In order to achieve this they looked for a correlation between some indicators of good physical health, such as the android fat mass, the lean body mass, balance and the strength of grip, the strength of the torso and the strength of the lower limbs. They found that the levels of vitamin D were correlated with all these factors except strength of torso and lower limbs, concluding that levels of vitamin D may contribute to these indices of physical health in healthy postmenopausal women ${ }^{24}$.

In addition, and in agreement with what has been said earlier, various studies have shown that vitamin D supplements improve considerably muscle strength, especially in the elderly population with hypovitaminosis. Bunout et al. evaluated the effects of resistance training and the provision of vitamin D supplements on the physical condition of 96 healthy older people with low levels of vitamin $\mathrm{D}$, concluding that its addition improved the speed of movement and stability, while the training improved muscle strength ${ }^{25}$. In a randomised placebo-controlled study, carried out in outpatients over 65 years of age with a history of falls and hypovitaminosis, and whose aim was to see the effect on physical and muscle function of a vitamin D supplement (ergocalciferol) administered in a single intramuscular dose of 600,000 UI, the authors found as a result that, at 6 months, the subjects who had received the vitamin D supplement achieved significant benefits in physical function, reaction time and balance, although not in muscle strength ${ }^{26}$. In a study by Bischoff-Ferrari et al. the authors demonstrated that vitamin $\mathrm{D}$ with calcium improves the postural and dynamic balance of institutionalised older people ${ }^{27}$. Moreira-Pfrimer et al. studied muscle strength in 46 institutionalised subjects of $\geq 65$ years of age, to whom had been administered randomly over 6 months, either daily calcium plus placebo, or daily calcium plus vitamin D. By the end of the study, and in the absence of physical exercise, the strength of the hip flexors increased in the group who received vitamin $\mathrm{D}$ by $16.4 \%$ $(p=0.0001)$, and the strength of the extensors in the knee by $24.6 \%(\mathrm{p}=0.0007)^{28}$.

However, there are studies which conclude that in healthy older people vitamin D supplements do not prevent the decrease in muscle strength due to age-related regression ${ }^{29,30}$. In a review carried out by Annweiler et al., the results regarding the association between vitamin $\mathrm{D}$ and physical function were $\operatorname{arguable}^{31}$, although a more recent meta-analysis concluded that vitamin D supplements at daily doses of 800 to 1,000 UI were shown to have beneficial effects on muscle strength and balance in older people ${ }^{32}$.

Muscle weakness associated with hypovitaminosis D, if a certain limit is surpassed, may affect functional capacity and mobility, which puts especially older people at greater risk of falls, and therefore of fracture ${ }^{26,30}$. A study carried out in institutionalised older women showed that those who took calcium and vitamin $\mathrm{D}$ for 3 months had a reduction in the risk of falls of $49 \%$ compared with those who only took calcium, and their musculo-skeletal function improved significantly $(p=0.0094)^{33}$. Similar results were obtained by Pfeifer et al. in a study carried out in older people of both sexes ${ }^{34}$. With regard to the effect on falls of vitamin $\mathrm{D}$, in a placebo-controlled randomised study of multiple doses, it was shown that the administration of $800 \mathrm{UI} /$ day of vitamin D for more than 5 months reduced the adjusted-incidence rate of falls by $72 \% 35$. Various meta-data analyses published in recent years indicate that vitamin D supplements reduce the risk of falls in older people $^{36}$. One of these, carried out by Bischoff-Ferrari et al. with 8 randomised placebo-controlled trials $(n=2,426)$, showed that vitamin D supplements at doses of 700 to 1,000 UI/day, or blood levels of vita$\min \mathrm{D} \geq 24 \mathrm{ng} / \mathrm{ml}$, reduces the risk of falls by $19 \%$ and $23 \%$ respectively. No benefits were observed with lower doses of supplements or levels of blood vitamin $\mathrm{D}$ than those indicated ${ }^{37}$. This observation is corroborated in a Cochrane review carried out in 2009 by Gillespie et al. who observed that vitamin D supplements did not reduce the risk of falls $(\mathrm{RR}=0.96,95 \% \mathrm{CI}: 0.92-1.10)$, but indicated that they may do so in people with low blood levels of vitamin $D^{38}$. In another review it was concluded that these supplements reduce the rate of falls (rate ratio $\mathrm{RaR}=0.72 ; 95 \%$ CI: $0.55-0.95)$ but not the risk of falls (risk ratio $\mathrm{RR}=0.98$; 95\% CI: $0.89-1.09)^{39}$. In a systematic review accompanied by a meta-analysis carried out by Kalyani et al., the authors obtained the result that vitamin $\mathrm{D}$ supplements effectively reduce the risk of falls in older women ${ }^{40}$.

In conclusion, there is evidence that the muscle responds to vitamin $\mathrm{D}$, which ought to be an incentive for carrying out studies into its therapeutic potential in muscular pathologies. Furthermore, the evidence is sufficient to recommend that doctors take into account the observation of levels of vitamin D in patients with muscular disorders. 


\section{Vitamin D and cancer}

The first publication on the association between exposure to sun and the reduction in mortality due to cancer in the US was produced in 1941 by Apperly ${ }^{41}$. Much later, in 1980, the Garland brothers proposed the hypothesis that vitamin $\mathrm{D}$ is a protector against cancer of the colon ${ }^{42}$. Since then, there have been many epidemiological studies aimed at evidencing this relationship, as well as with other types of cancer, mostly showing positive results. A recent systematic review carried out by Grant found a strong inverse relationship between sun exposure-vitamin D and the appearance of 15 different types of cancer: vesical, breast, uterine, colon, endometrial, oesophageal, gastric, lung, ovarian, pancreatic, rectal, renal, vulvar and Hodgkin and non-Hodgkin lymphoma ${ }^{43}$. Lappe et al., in a placebo-controlled double blind randomised trial carried out in 1,179 postmenopausal women to whom were assigned treatment with calcium only, or calcium and vitamin D or placebo found that improvements in the nutritional state of calcium and vitamin D reduced the risk of suffering any type of cancer ${ }^{44}$.

In another more recent systematic review, van der Rhee et al. ${ }^{45}$ found that almost all the epidemiological studies reviewed suggested that chronic (not intermittent) exposure to sun is associated with a reduced risk of colorectal, breast, and prostate cancer and non-Hodgkin lymphoma. In the case of colorectal cancer - and to a lesser degree in breast cancer - the levels of vitamin D are inversely associated with the risk of cancer, but not so in prostate cancer or in non-Hodgkin lymphoma. Other retrospective and prospective case-controlled studies, however, have found this inverse relationship in four types of cancer, colon, prostate, breast and non-Hodgkin lymphoma ${ }^{46-52}$, although a recently published study found no association in the case of prostate cancer ${ }^{53}$. Vitamin D and its analogues inhibit the proliferation, the angiogenesis, the migration and the invasion of the malignant line cells of cancer of the colon, prostate and breast, and induce their differentiation and apoptosis ${ }^{54,55}$. Furthermore, the synthesis of prostaglandins and the Wnt/beta catenin signalling pathway are also influenced by vitamin D, which suppresses COX-2 expression and increases that of 15-PGDH, thus reducing levels of inflammatory prostaglandins. Thus are prostaglandin metabolism and signalling regulated, hence diminishing the promotion of the carcinogenesis promoted by them. This effect on the synthesis of prostaglandins also gives rise to a suppression of tumoral angiogenesis, by means of the regulation of the crucial factors which control $\mathrm{it}^{56,57}$. Vitamin D also regulates the signalling of the androgen and estrogen receptors, thus inhibiting the growth of some tumours dependent on these hormones, such as those of the breast and the prostate, reducing also in the latter the expression of aromatase, which contributes to the inhibition of its growth ${ }^{8,59}$.

Association studies have certain limitations in terms of the establishment of a causal relationship between vitamin D status and a reduced risk of cancer. For example, low levels of vitamin D are also linked to confusion factors related to a greater risk of cancer, such as obesity, (as we see later, vitamin D is "retained" in adipose tissue) and a lack of physical activity (correlated with less time in the open air and exposure to sun $)^{50}$. However, a double blind, randomised placebo-controlled trial of 4 years duration, carried out in more than a thousand postmenopausal women, whose principal secondary objective was the incidence of cancer, showed that the administration of calcium supplements (1,400-1,500 mg/day) and vitamin D $(1,100 \mathrm{UI} /$ day) reduced the relative risk of cancer by approximately $60 \%(\mathrm{p}<0.01)$. The repetition of an analysis of cancer-free survival after the first 12 months revealed that the relative risk for the group with calcium and vitamin $\mathrm{D}$ was reduced by approximately 77\% (95\% CI: 0.09-0.60; p<0.005). Multiple regression models also show that treatment and blood concentrations of vitamin $\mathrm{D}$ are significant independent predictors of the risk of cancer ${ }^{44}$.

Evidently, studies which relate vitamin D deficiency to the risk of cancer do not show that this is a causal relationship. More clinical trials are necessary aimed specifically at looking at the effects of vitamin D supplements in the development of neoplasms, and whether the maintenance of sufficient levels of vitamin D may be an effective preventative measure.

\section{Vitamin D and metabolic diseases: diabetes and obesity}

The hypothesis that vitamin D may be relevant to the risk of diabetes is consistent, given the numerous studies which have shown an inverse association between vitamin D deficiency and the disease, especially type 2 .

A meta-analysis carried out in order to observe the association between the status of vitamin D or its supplement and the incidence of type 2 diabetes showed that those subjects with levels of the hormone $>25 \mathrm{ng} / \mathrm{ml}$, compared with those who had levels $<14 \mathrm{ng} / \mathrm{ml}$, had a $43 \%$ lower risk of developing type 2 diabetes, and that a daily supplement of vitamin D higher than 500 UI, compared with one $<200 \mathrm{UI} /$ day, reduced the risk by $13 \%{ }^{60}$. Another study carried out by George et al., concluded however that there was not sufficient evidence of the beneficial effects to recommend vitamin D supplements as a measure to improve glycemia or resistance to insulin in patients with diabetes $^{61}$. Song et al. have published another more recent study in which they conclude that there is a reduction of $38 \%$ in the risk of suffering diabetes type 2 when comparing people with higher levels of vitamin $\mathrm{D}$ with those with lower levels ( $R R=0.62 ; 95 \%$ CI, 0.54-0.70) ${ }^{62}$. The Nurses' Health Study conducted a follow up study of more than 83,000 women and it was observed that a daily intake of calcium $>1,200 \mathrm{mg}$ plus a vitamin D supplement $>800$ UI was associated with a lower risk (33\%) of suffering diabetes type 2 $(\mathrm{RR}=0.67$; 95\% CI: 0.49-0.90) compared with an 
intake of calcium $<600 \mathrm{mg}$ plus 400 UI of vitamin $\mathrm{D}^{63}$. A prospective study which followed up more than 2,000 participants showed that the risk of progression from pre-diabetes to diabetes was $62 \%$ lower when those with levels of vitamin D in the highest quartile were compared with those who had levels in the lowest quartile ${ }^{64}$. This could be explained by the findings which indicate that vitamin D exerts various anti-diabetic effects ${ }^{65}$. The VDR is expressed in the pancreatic beta cells, and vitamin D stimulates the secretion of insulin ${ }^{66,67}$. Various studies have shown that vitamin D supplements result in an improved sensitivity to insulin ${ }^{6870}$, mediated, for example, by an increase in the production of insulin receptors ${ }^{66}$, and modulates inflammation, which it is thought, also plays a role in diabetes type $2^{67,71}$.

On the other hand, it has also been demonstrated that obese subjects have lower levels of vitamin $\mathrm{D}$ than those who are not obese $\mathrm{e}^{72-77}$. These lower levels have been explained by, among other factors, the storage of vitamin $\mathrm{D}$ in body fat ${ }^{78,79}$. Furthermore, these obese subjects respond less well to vitamin D supplements, their increase in vitamin $\mathrm{D}$ being less than in those who are not obese with the same dose of supplements, their needs therefore being greater ${ }^{72,76,77}$. In connection with what has been said earlier, some studies have shown that the correction of a vitamin D deficit in obese subjects improves sensitivity to insulin ${ }^{69}$, although some authors have not found a reduction in the resistance to insulin with vitamin D supplements in these subjects ${ }^{7,80}$. Indeed, in a recent randomised, double blind placebo-controlled study carried out by Salehpour et al. in 77 women who were overweight and obese, the authors found that the group of women who took vitamin D for 12 weeks showed a decrease in body fat mass significantly greater than the placebo group $(-2.7 \pm 2.1$ $\mathrm{kg}$ vs $0.47 \pm 2.1 \mathrm{~kg} ; \mathrm{p}<0.001)$, with a significant inverse correlation between the two parameters ( $r=-0.319, p=0.005)$, although the weight and the circumference of the wrist did not show any significant changes in either of the two groups ${ }^{81}$. These correlation data between vitamin D and body fat mass have already been reported by other authors ${ }^{82,83}$.

These common findings fit within the framework of the metabolic syndrome. In a study carried out in 4,727 healthy young people who were followed up over a period of 20 years, it was observed that the prevalence of the majority of the components of metabolic syndrome (abdominal obesity, hyperglycemia and low blood concentrations of HDL-cholesterol ) were reducing significantly over the quintiles for the intake of vitamin $\mathrm{D}(\mathrm{p}=0.05)$.

There was a significant inverse association between the intake through the diet or by supplements of vitamin $\mathrm{D}$ and the risk of developing metabolic syndrome at 20 years $^{84}$. Another follow up study over 5 years with 11,547 adults carried out in Australia observed that low levels of vitamin D were inversely correlated with a greater risk of metabolic syndrome, greater wrist circumference, higher levels of blood glucose and triglycerides, and greater resistance to insulin ${ }^{85}$. It has been observed in obese subjects that vitamin D supplements reduce levels of GH and IGF, which means that the adverse affects of the GH-IGF-insulin axis in the metabolism of glucose and the metabolic syndrome may be in part related to the deficit status of vitamin $\mathrm{D}^{74}$.

All these studies demonstrate the involvement of vitamin $\mathrm{D}$ in the metabolism, although there are still many unknowns regarding its involvement in diabetes mellitus type 2 and obesity, and more generally, in metabolic syndrome, as well as in its etiopathogeny, and its potential therapeutic effect.

\section{Vitamin D and diabetes mellitus type 1}

There have also been studies carried out which look at the influence of vitamin D on diabetes type $1^{86}$. With a different etiopathogeny to type 2, diabetes type 1 may have a connection with vitamin D through its action on the immune system ${ }^{87}$, which we analyse in the following section. Littorin et al. observed that young adults recently diagnosed with diabetes type 1 had lower levels of vitamin $\mathrm{D}$ than those subjects without the disease, who acted as a $\mathrm{control}^{88}$. Sorensen et al. followed up 29,072 pregnant women and their offspring, and observed that the children of the women who had lower levels of vitamin D during pregnancy had double the risk of suffering diabetes type 1 than those of mothers with higher levels ${ }^{89}$. A study carried out in a cohort of new-born babies who were followed up over a year found that those who took vitamin D supplements, both regularly and irregularly, had a lower relative risk of suffering diabetes type 1 than those who did not do so $(\mathrm{RR}=0.12 ; 95 \% \mathrm{CI}, 0.03-0.51$ and $\mathrm{RR}=0.16$; 95\% CI, 0.04-0.74, respectively) ${ }^{90}$. Li et al studied 35 patients with latent autoimmune diabetes who were randomly assigned either to a group treated with insulin only or to a group treated with insulin and vitamin $\mathrm{D}$ for a year. At the end of this study the levels of $\mathrm{C}$ peptide diminished in the group treated with insulin only $(\mathrm{p}=0.006)$, while in the group treated with vitamin D also remained stable. $70 \%$ of the patients treated with vitamin $\mathrm{D}$ maintained or increased their levels of C peptide, while $22 \%$ of those treated with insulin alone did so, the difference being significant $(\mathrm{p}=0.01)^{91}$.

A meta-analysis of observational studies concluded that vitamin D supplements at early ages may offer protection against the development of diabetes type $1^{92}$. However, other authors did not find this protective effect of vitamin D in subjects with recently occurring diabetes type $1^{93,94}$ which means that more studies are required to help elucidate whether vitamin D may bring additional benefits to the treatment of these patients.

\section{Vitamin D and the immune system}

The participation of vitamin D in immunity has been studied for many years. VDRs are present in all the cells of the immune system ${ }^{95}$, and a great number of genes related to the immune system are regulated by vitamin $\mathrm{D}^{96}$. 
Its involvement has been demonstrated both in natural and innate immunity (the beneficial effects of sunlight in patients with tuberculosis has been known for some time) and in acquired immunity. Vitamin D improves the antimicrobial effects of the macrophages and monocytes, as well as chemotaxis and the phagocytic capacity of these cells $^{97}$. Cathelicidin and $\beta 2$ defensin are antimicrobial peptides which act to destabilise the microbial membrane, and are produced by polimorphonuclears and macrophages. Vitamin D, through its VDR (along with the X retinoid receptors) directly activates the transcription of these peptides and their production ${ }^{98-100}$. In a study carried out in critical patients (with and without sepsis) the levels of vitamin $\mathrm{D}$ and cathelicidin were determined and compared with those of a group of healthy subject, and it was observed that the critical patients had lower values of both than the healthy subjects, and a positive and significant correlation between levels of vitamin D and cathelicidin was found ${ }^{101}$. There are also studies which show that vitamin $\mathrm{D}$ modulates the maturation of dendritic cells $^{102,103}$. On the other hand, it has been reported that vitamin $\mathrm{D}$ inhibits the cytokines of the T cells such as IL-2 and 17, and the toll-like receptors of the monocytes responsible for the recognition of a wide range of microbial agents and for the stimulation of the inflammatory response to them ${ }^{97}$. Finally, it has been confirmed that high doses of vitamin $\mathrm{D}$ in healthy subjects leads to a reduction in IL-6 (pro-inflammatory cytokine) produced by the monocytes ${ }^{104}$.

All this, combined with various studies which have found low levels of vitamin $\mathrm{D}$ in patients with different infectious respiratory diseases ${ }^{105-108}$, and others which provide evidence of a more rapid recovery in patients with tuberculosis in those to whom vitamin D supplements are administered $^{109,110}$, supports the theory of the participation of vitamin D in natural immunity.

With respect to acquired immunity, vitamin D regulates the differentiation and proliferation of the $\mathrm{T}$ and $\mathrm{B}$ lymphocytes, especially when these have been activated, since it has been confirmed that in the state of cell activity the expression of genes activated by vitamin $D$ though its nuclear receptors specific to these cells increases considerably, genes which are involved in the regulation of the proliferation and differentiation of these lymphocytes ${ }^{111,112}$. In the B lymphocytes this action has been seen to occur indirectly through the $\mathrm{T}$ lymphocyte co-operators or helpers, which induce the inhibition of the proliferation and differentiation of the B lymphocytes and the initiation of their apoptosis, as well as a lower production of immunoglobulins ${ }^{113,114}$. However, more recent studies have shown a direct effect of vitamin D on the B lymphocytes ${ }^{97,111,115}$.

With respect to the activated $\mathrm{T}$ lymphocytes, vitamin D leads to a state of greater immune tolerance, suppressing the proliferation and differentiation of the $\mathrm{T}$ lymphocyte co-operators and modulating the production of its cytokines ${ }^{113}$, inhibiting the pro-inflammatory cytokines (IL-2, inter- feron- $\boldsymbol{\gamma}$, TNF $\alpha$, IL-9, IL-22) $)^{96,116-118}$, and promoting the production of anti-inflammatory cytokines (IL3, IL-4, IL-5, IL-10) ${ }^{119}$

As a consequence, the relationship described by various authors between vitamin D deficiency and autoimmune diseases such as diabetes type 1 (as we have already mentioned), rheumatoid arthritis ${ }^{120}$, systemic lupus erythematosus ${ }^{121}$, multiple sclerosis $^{122}$, psoriasis ${ }^{123}$, chronic inflammatory intestinal disease ${ }^{124}$, etc, is not surprising. Although, as has already been said in relation to cancer, more studies should be carried out to discover the true involvement of vitamin $\mathrm{D}$ in the pathogeny of these diseases.

\section{Conclusions}

It is clear that vitamin D has an involvement in general health, and that it does not only benefit bone. Apart from the functions discussed above, numerous studies have looked at its relationship with other functions such as reproduction, the nervous system, cardiovascular disease, etc. We should not forget the close relationship which exists between vitamin D and calcium, a molecule which also has a wide involvement in cell function. To what extent vitamin $\mathrm{D}$ is involved in physiology outside the bone is yet to be determined. However, the ever more numerous studies which are carried out in this area are leading the way and inviting researchers to continue to deepen the understanding of the actions of this vitamin, which has become a calciotropic hormone, and which may perhaps become to be seen, as with the thyroid hormones, as a hormone which acts multisystemically.

\section{Bibliography}

1. McCollum EV, Simmonds N, Becker JE, Shipley PG. Studies on experimental rickets. XXI. An experimental demostration of the existence on a vitamin wich promotes calcium depositins. J Biol Chem 1922;53:293-312.

2. Lawson DE, Fraser DR, Kodicek E, Morris HR, William DH. Identification of 1,22, dihydroxycholecalciferol, a new kidney hormone controlling calcium metabolism. Nature 1971;230:228-30.

3. Bouillon R, Carmeliet G, Verlinden L, van Etten E, Verstuyf A, Luderer HF, et al. Vitamin D and human health: lessons from vitamin $\mathrm{D}$ receptor null mice. Endocr Rev 2008;29:726-76.

4. Hossein-nezhad A, Spira A, Holick MF. Influence of vitamin D status and vitamin D3 supplementation on genome wide expression of white blood cells: a randomized double-blind clinical trial. PLoS One 2013;8:e58725.

5. Wacker M, Holick MF. Vitamin D-Effects on skeletal and extraskeletal health and the need for supplementation. Nutrients 2013;5:111-48.

6. Bouillon R, Van Schoor NM, Gielen E, Boonen S, Mathieu C, Vanderschueren D, et al. Optimal vitamin D status: a critical analysis on the basis of evidence-based medicine. J Clin Endocrinol Metab 2013;98:E1283-304.

7. Boland R. Role of vitamin D in skeletal muscle function. Endocr Rev 1986;7:434-48.

8. Bischoff HA, Borchers M, Gudat E Duermueller U, Theiler R, Stähelin HB, et al. In situ detection of 1,25 dihydroxyvitamin D3 recettor in human skeletal muscle tissue. Histochem J 2001;33:19-24.

9. Ceglia L, da Silva Morais M, Park LK, Morris E, Harris 
SS, Bischoff-Ferrari HA, et al. Multi-step inmunofluorescent analysis of vitamin $\mathrm{D}$ receptor loci and myosin heavy chain isoforms in human skeletal muscle. J Mol Histol 2010;41:137-42.

10. Bischoff-Ferrari H. Relevance of vitamin D in muscle health. Rev Endocr Metab Disord 2012;13:71-7.

11. Bischoff-Ferrari HA, Borchers M, Gudat F, Durmuller $\mathrm{U}$, Stahelin HB, Dick W. Vitamin D receptor expression in human muscle tisuue decreases with age. J Bone Miner Res 2004;19:265-9.

12. Boland R. VDR activation of intracellular signaling pathways in skeletal muscle. Mol Cell Endocrinol 2011:34:11-6.

13. Buitrago C, Pardo VG, Boland R. Role of VDR in 1 $\alpha, 25$-dihydroxyvitamin D3-dependent non-genomic activation of MAPKs, Src and Akt in skeletalmuscle cells. J Steroid Biochem Mol Biol 2013;136:125-30.

14. Max D, Brandsch C, Schumann S, Kühne $\mathrm{H}$, Frommhagen M, Schutkowski A, et al. Maternal vitamin D deficiency causes smaller muscle fibers and altered transcript levels of genes involved in protein degradation, myogenesis, and cytoskeleton organization in the newborn rat. Mol Nutr Food Res 2013 Aug 21. [Epub ahead of print].

15. Wang Y, De Luca HF. Is the vitamin D receptor found in muscle? Endocrinology 2011;152:354-63.

16. Girgis CM, Clifton-Bligh RJ, Hamrick MW, Holick MF, Gunton JE. The Roles of vitamin d in skeletal muscle: form, function, and metabolism. Endocrine Rev 2013;34:33-83

17. Endo I, Inoue D, Mitsui T, Umaki Y, Akaike M, Yoshizawa $\mathrm{T}$, et al. Deletion of vitamin $\mathrm{D}$ receptor gene in mice results in abnormal skeletal muscle development with deregulated expression of myoregulatory transcription factors. Endocrinology 2003;144:5138-44.

18. Khanal R, Nemere I. Membrane receptors for vitamin D metabolites. Crit Rev Eukaryot Gene Expr 2007;17:31-47.

19. Dawson-Hughes B. Serum 25-hydroxyvitamin D and muscle atrophy in the elderly. Proc Nutr Soc 2012;71:46-9.

20. Schott GD, Wills MR. Muscle weakness in osteomalacia. Lancet 1976;307:626-9.

21. Holick MF. Vitamin D deficiency. N Engl J Med 2007:357:266-81

22. Glerup H, Mikkelsen K, Poulsen L, Hass E, Overbeck $\mathrm{S}$, Andersen $\mathrm{H}$, et al. Hypovitaminosis D myopathy without biochemical signs of osteomalacic bone involvement. Calcif Tissue Int 2000;66:419-24

23. Wicherts IS, van Schoor NM, Boeke AJP, Visser M, Deeg DJH, Smit J, et al. Vitamin D status predicts physical performance and its decline in older persons. J Clin Endocrinol Metab 2007:92:2058-65.

24. Stewart JW, Alekel L, Tirland LM, Van Lan M, Gertz E, Genschel U. Serum 25-hydroxyvitamin D is relates to indicators of overall physical fitness in healthy postmenopausal women. Menopause 2009;16:1093-101.

25. Bunout D, Barrera G, Leiva L, Gattas V, de la Maza MP, Avendaño M, et al. Effects of vitamin D supplementation and exercise training on physical performance in Chilean vitamin D deficient elderly subjects. Exp Gerontol 2006;41:746-52

26. Dhesi J, Jackson S, Bearne L, Moniz C, Hurley M, Swift C, et al. Vitamin D supplementation improves neuromuscular function in older people who fall. Age and Aging 2004:33:589-95.

27. Bischoff-Ferrari H, Conzelmann M, Stähelin H, Dick W, Carpenter M, Adkin A, et al. Is fall prevention by vitamin D mediated by a change in postural or dynamic balance? Osteoporos Int 2006;17:656-63.

28. Moreira-Pfrimer LD, Pedrosa MA, Teixeira L, LazzarettiCastro M. Treatment of vitamin D deficiency increases coger limb muscle stregth in institutionalized older people independently of regular physical activity: a randomizad double-blind controlled trial. Ann Nutr Metab 2009;54:291-300

29. Ceglia L. Vitamin D and its role in skeletal muscle. Curr Opin Clin Nutr Metab Care 2009;12:628-33.

30. Janssen H, Samson M, Verhaar H. Vitamin D deficiency, muscle function, and falls in elderly people. Am J Clin Nutr 2002;75:611-5.
31. Annweiler C, Schott AM, Beirut G, Fantino B, Beauchet O. Vitamina-related changes in physical performance: a systematic review. J Nutr Health Aging 2009;13:893-8.

32. Muir SW, Montero-Odasso M. Effect of vitamin D supplementation on muscle strength, gait and balance in older adults: a systematic review and meta-analysis. J Am Geriatr Soc 2011:59:2291-300.

33. Bischoff HA, Stähelin HB, Dick W, Akos R, Knecht M, Salis C, et al. Effects of vitamin D and calcium supplementation on falls: A randomized controlled trial. J Bone Miner Res 2003;18:343-51

34. Pfeifer M, Begerow B, Minne HW, Suppan K, Fahrleitner-Pammer A, Dobnig H. Effects of a longterm vitamin D and calcium supplementation on falls and parameters of muscle function in community-dwelling older individuals. Osteoporos Int 2009;20:315-22.

35. Broe KE, Chen TC, Weinberg J, Bischoff-Ferrari HA, Holick MF, Kiel DP. A higher dose of vitamin D reduces the risk of falls in nursing home residents: A randomized, multiple-dose study. J Am Geriatr Soc 2007;55:234-9.

36. Jackson C, Gaugris S, Sen SS, Hosking D. The effect of cholecalciferol (vitamin D3) on the risk of fall and fracture: a meta-analysis. Q J Med 2007:100:185-92.

37. Bischoff-Ferrari HA, Dawson-Hughes B, Staehelin HB, Orav JE, Stuck AE, Theiler R, et al. Fall prevention with supplemental and active forms of vitamin D: A metaanalysis of randomised controlled trials. BMJ 2009;339:b3692.

38. Gillespie LD, Robertson MC, Gillespie WJ, Lamb SE, Gates S, Cumming RG, et al. Interventions for preventing falls in older people living in the community. Cochrane Database Syst Rev 2009;15:CD007146.

39. Cameron ID, Murray GR, Gillespie LD, Robertson MC, Hill $\mathrm{KD}$, Cumming RG, et al. Interventions for preventing falls in older people in nursing care facilities and hosptitals. Cochrane Database Syst Rev 2010;20:CD005465.

40. Kalyani RR, Stein B, Valiyil R, Manno R, Maynard JW, Crews DC. Vitamin D treatment for the prevention of falls in older adults: systematic review and meta-analysis. J Am Geriatr Soc 20101;58:1299-310.

41. Apperly FL. The relation of solar radiation to cancer mortality in North America. Cancer Res 1941;1:191-5.

42. Garland CF, Garland FC. Do sunlight and vitamin D reduce the likelihood of colon cancer? Int J Epidemiol 1980;9:227-31.

43. Grant WB. Ecological studies of the UVB-vitamin Dcancer hypothesis. Anticancer Res 2012;32:223-36.

44. Lappe JM, Travers-Gustafson D, Davies KM, Recker RR, Heaney RP. Vitamin D and calcium supplementation reduces cancer risk: Results of a randomized trial. Am J Clin Nutr 2007;85:1586-91.

45. van der Rhee H, Coebergh JW, de Vries E. Is prevention of cancer by sun exposure more than just the effect of vitamin D? A systematic review of epidemiological studies. Eur J Cancer 2013;49:1422-36.

46. Kricker A, Armstrong B. Does sunlight have a beneficial influence on certain cancers? Prog Biophys Mol Biol 2006;92:132-9.

47. Li H, Stampfer MJ, Hollis JB, Mucci LA, Gaziano JM, Hunter D, et al. A prospective study of plasma vitamin D metabolites, vitamin D receptor polymorphisms, and prostate cancer. LoS Med 2007;4:e103.

48. Drake MT, Maurer MJ, Link BK, Habermann TM, Ansell SM, Micallef IN, et al. Vitamin D insufficiency and prognosis in non-Hodgkin's lymphoma. J Clin Oncol 2010;28:4191-8

49. Freedman DM, Looker AC, Chang SC, Graubard BI. Prospective study of serum vitamin D and cancer mortality in the United States. J Natl Cancer Inst 2007:99:1594-602.

50. Manson JE, Mayne ST, Clinton SK. Vitamin D and prevention of cancer-Ready for prime time? N Engl J Med 2011;364:1385-7

51. Shin MH, Holmes MD, Hankinson SE, Wu K, Colditz GA, Willett WC. Intake of dairy products, calcium, and vitamin D and risk of breast cancer. J Natl Cancer Inst 2002;94;1301-10.

52. Feskanich D, Ma J, Fuchs CS, Kirkner GJ, Hankinson $\mathrm{SE}$, Hollis BW, et al. Plasma vitamin D metabolites and 
risk of colorectal cancer in women. Cancer Epidemiol Biomarkers Prev 2004;13:1502-8.

53. Holt SK, Kolb S, Fu R, Horst R, Feng Z, Stanford JL. Circulating levels of 25-hydroxyvitamin $\mathrm{D}$ and prostate cancer prognosis. Cancer Epidemiol 2013;37:666-70.

54. Krishnan AV, Trump DL, Johnson CS, Feldman D. The role of vitamin D in cancer prevention and treatment. Endocrinol Metab Clin North Am 2010;39:401-18.

55. Deeb KK, Trump DL, Johnson CS. Vitamin D signalling pathways in cancer: potential for anticancer therapeutics. Nat Rev Cancer 2007;7:684-700.

56. Krishnan AV, Feldman D. Mechanisms of the anti-cancer and anti-inflammatory actions of vitamin D. Annu Rev Pharmacol Toxicol 2011;51:311-36.

57. Leyssens C, Lieve Verlinden L, Verstuyf A. Antineoplastic effects of $1,25(\mathrm{OH}) 2 \mathrm{D} 3$ and its analogs in breast, prostate and colorectal cancer. Endocr Relat Cancer 2013;20:R31-47.

58. Godoy AS, Chung I, Montecinos VP, Buttyan R, Johnson CS, Smith GJ. Role of androgen and vitamin D receptors in endothelial cells from benign and malignant human prostate. Am J Physiol Endocrinol Metab 2013;304:E1131-9.

59. Krishnan AV, Swami S, Feldman D. The potential therapeutic benefits of vitamin $\mathrm{D}$ in the treatment of estrogen receptor positive breast cancer. Steroids 2012;77:1107-12.

60. Mitri J, Muraru MD, Pittas AG. Vitamin D and type 2 diabetes: A systematic review. Eur J Clin Nutr 2011;65:1005-15.

61. Pearson ER, Witham MD. Effect of vitamin D supplementation on glycaemic control and insulin resistance: a systematic review and meta-analysis. Diabet Med 2012;29:e142-50.

62. Song Y, Wang L, Pittas AG, Del Gobbo LC, Zhang C, Manson JE, et al. Blood 25-hydroxy vitamin D levels and incident type 2 diabetes: a meta-analysis of prospective studies. Diabetes Care 2013;36:1422-8.

63. Pittas AG, Dawson-Hughes B, Li T, van Dam RM, Willett WC, Manson JE, et al. Vitamin D and calcium intake in relation to type 2 diabetes in women. Diabetes Care 2006;29:650-6.

64. Deleskog A, Hilding A, Brismar K, Hamsten A, Efendic S, Östenson CG. Low serum 25-hydroxyvitamin D level predicts progression to type 2 diabetes in individuals with prediabetes but not with normal glucose tolerance. Diabetologia 2012;55:1668-78.

65. Boucher BJ. Vitamin D insufficiency and diabetes risks. Curr Drug Targets 2011;12:61-87.

66. Pilz S, Tomaschitz A, März W, Drechsler C, Ritz E, Zittermann A, et al. Vitamin D, cardiovascular disease and mortality. Clin Endocrinol 2011;75:575-84

67. Wolden-Kirk H, Overbergh L, Christesen HT, Brusgaard K, Mathieu C. Vitamin D and diabetes: Its importance for beta cell and immune function. Mol Cell Endocrinol 2011:347:106-20.

68. von Hurst PR, Stonehouse W, Coad J. Vitamin D supplementation reduces insulin resistance in South Asian women living in New Zealand who are insulin resistant and vitamin D deficient - a randomised, placebocontrolled trial. Br J Nutr 2010;103:549-55.

69. Belenchia AM, Tosh AK, Hillman LS, Peterson CA. Correcting vitamin D insufficiency improves insulin sensitivity in obese adolescents: a randomized controlled trial. Am J Clin Nutr 2013;97:774-81.

70. Harris SS, Pittas AG, Palermo NJ. A randomized, placebo-controlled trial of vitamin D supplementation to improve glycaemia in overweight and obese African Americans. Diabetes Obes Metab 2012;14:789-94.

71. Holick MF. Nutrition: Diabetes and Death Defying vitamin D. Nat Rev Endocrinol 2012;8:388-90.

71. Wortsman J, Matsuoka LY, Chen TC, Lu Z, Holick MF. Decreased bioavailability of vitamin D in obesity. Am J Clin Nutr 2000;72:690-3.

73. Yanoff LB, Parikh SJ, Spitalnik A, Denkinger B, Sebring NG, Slaughter P, et al. The prevalence of hypovitaminosis D and secondary hyperparathyroidism in obese black americans. Clin Endocrinol 2006:64:s23-s9.

74. Kamycheva E, Berg V, Jorde R. Insulin-like growth factor I, growth hormone, and insulin sensitivity: the effects of a one-year cholecalciferol supplementation in middle-aged overweight and obese subjects. Endocrine 2013;43:412-8.

75. Vimaleswaran KS, Berry DJ, Lu C, Tikkanen E, Pilz S, Hiraki LT, et al. Causal Relationship between Obesity and Vitamin D Status: Bi-Directional Mendelian Randomization Analysis of Multiple Cohorts. PLoS Med 2013;10:e1001383.

76. Aguirre Castaneda R, Nader N, Weaver A, Singh R, Kumar S. Response to vitamin D3 supplementation in obese and non-obese Caucasian adolescents. Horm Res Paediatr 2012;78:226-31.

77. Gallagher C, Yalamanchili V, Smith LM. The effect of vitamin D supplementation on serum $25(\mathrm{OH}) \mathrm{D}$ in thin and obese women. I Steroid Biochem Mol Biol 2013;136:195-200

78. Danescu LG, Levy S, Levy J. Vitamin D and diabetes mellitus. Endocrine 2009;35:11-7.

79. Bays HE, González-Campoy JM, Bray GA, Kitabchi AE, Bergman DA, Schorr AB, et al. Pathogenic potential of adipose tissue and metabolic consequences of adipocyte hypertrophy and increased visceral adiposity. Expert Rev Cardio Ther 2008,6:343-68.

80. Beilfuss J, Berg V, Sneve M, Jorde R, Kamycheva E. Effects of a 1-year supplementation with cholecalciferol on interleukin-6, tumor necrosis factor-alpha and insulin resistance in overweight and obese subjects. Cytokine 2012;60:870-4.

81. Salehpour A, Hosseinpanah F, Shidfar F, Vafa M, Razaghi M, Dehghani S, et al. A 12-week double-blind randomized clinical trial of vitamin D3 supplementation on body fat mass in healthy overweight and obese women. Nutr J 2012;11:78-85.

82. Siddiqui SM, Chang E, Li J, Burlage C, Zou M, Buhman $\mathrm{KK}$, et al. Dietary intervention with vitamin D, calcium, and whey protein reduced fat mass and increased lean mass in rats. Nutr Res 2008:28:783-90.

83. Rosenblum JL, Castro VM, Moore CE, Kaplan LM. Calcium and vitamin D supplementation is associated with decreased abdominal visceral adipose tissue in overweight and obese adults. Am J Clin Nutr 2012;95(Suppl 1):101-8

84. Fung GF, Steffen LM, Zhou X, Harnack L, Tang W, Lutsey PL, et al. Vitamin D intake is inversely related to risk of developing metabolic syndrome in African American and white men and women over $20 \mathrm{y}$ : the Coronary Artery Risk Development in Young Adults study. Am J Clin Nutr 2012;96:24-9.

85. Gagnon C, Lu ZX, Magliano DJ, Dunstan DW, Shaw JE, Zimmet PZ, et al. Low serum 25 -hydroxyvitamin D is associated with increased risk of the development of the metabolic syndrome at five years: results from a national, population-based prospective study (The Australian Diabetes, Obesity and Lifestyle Study: AusDiab). J Clin Endocrinol Metab 2012;97:1953-61.

86. Hyppönen E. Vitamin D and increasing incidence of type 1 diabetes-evidence for an association? Diabetes Obes Metab 2010;12:737-43.

87. Badenhoop K, Kahles H, Penna-Martinez M. Vitamin $\mathrm{D}$, immune tolerance, and prevention of type 1 diabetes. Curr Diab Rep 2012:12:635-42.

88. Littorin B, Blom P, Schölin A, Arnqvist HJ, Blohmé G, Bolinder J, et al. Lower levels of plasma 25 -hydroxyvitamin D among young adults at diagnosis of autoimmune type 1 diabetes compared with control subjects: results from the nationwide Diabetes Incidence Study in Sweden (DISS). Diabetologia 2006; 49:2847-52.

89. Sørensen IM, Joner G, Jenum PA, Eskild A, Torjesen PA, Stene LC. Maternal serum levels of 25-hydroxyvitamin D during pregnancy and risk of type 1 diabetes in the offspring. Diabetes 2012;61:175-8.

90. Hyppönen E, Läärä E, Reunanen A, Järvelin MR, Virtanen SM. Intake of vitamin D and risk of type 1 diabetes: a birth-cohort study. Lancet 2001;358:1500-3.

91. Li X, Liao L, Yan X, Huang G, Lin J, Lei M, et al. Protective effects of 1-alpha-hydroxyvitamin D3 on residual beta-cell function in patients with adult-onset latent autoimmune diabetes (LADA). Diabetes Metab Res Rev 2009;25:411-6.

92. Zipitis CS, Akobeng AK. Vitamin D supplementation in early childhood and risk of type 1 diabetes: a systematic review and meta-analysis. Arch Dis Child 2008;93:512-7. 
93. Bizzarri C, Pitocco D, Napoli N, Di Stasio E, Maggi D, Manfrini S, et al. No protective effect of calcitriol on cell function in recent-onset type 1 diabetes. Diabetes Care 2010;33:1962-3.

94. Walter M, Kaupper T, Adler K, Foersch J, Bonifacio E, Ziegler AG. No Effect of the 1,25-Dihydroxyvitamin D3 on -Cell Residual Function and Insulin Requirement in Adults With New-Onset Type 1 Diabetes. Diabetes Care 2010;33:1443-8.

95. White JH. Vitamin D metabolism and signaling in the immune system. Rev Endocr Metab Disord 2012;13:21-9.

96. Baeke F, Korf H, Overbergh L, Verstuyf A, Thorrez L, Van Lommel L, et al. The vitamin D analog, TX527, promotes a human $\mathrm{CD} 4+\mathrm{CD} 25$ highCD127low regulatory $\mathrm{T}$ cell profile and induces a migratory signature specific for homing to sites of inflammation. Immunol 2011;186:132-42.

97. Baeke F, Takiishi T, Korf H, Gysemans C, Mathieu C. Vitamin D: Modulator of the immune system. Curr Opin Pharmacol 2010;10:482-96.

98. Wang T, Nestel FP, Bourdeau V, Nagai Y, Wang Q, Liao J. Cutting edge: 1,25-Dihydroxyvitamin D3 is a direct inducer of antimicrobial peptide gene expression. J Immunol 2004;173:2909-12.

99. Gombart AF, Borregaard N, Koeffler HP. Human cathelicidin antimicrobial peptide (CAMP) gene is a direct target of the vitamin D receptor and is strongly upregulated in myeloid cells by 1,25-dihydroxyvitamin D3. FASEB J 2005;19:1067-77.

100. Liu PT, Stenger S, Li H, Wenzel L, Tan BH, Krutzik SR, et al. Toll-like receptor triggering of a vitamin D-mediated human antimicrobial response. Science 2006;311:1770-3.

101. Jeng L, Yamshchikov AV, Judd SE, Blumberg HM, Martin GS, Ziegler TR, et al. Alterations in vitamin D status and anti-microbial peptide levels in patients in the intensive care unit with sepsis. J Transl Med 2009;7:28.

102. Piemonti L, Monti P, Sironi M, Fraticelli P, Leone BE, Dal Cin E, et al. Vitamin D3 affects differentiation, maturation, and function of human monocyte- derived dendritic cells. J Immunol 2000;164:4443-51.

103. Penna G, Amuchastegui S, Giarratana N, Daniel KC, Vulcano M, Sozzani S, et al. 1,25-Dihydroxyvitamin D3 selectively modulates tolerogenic properties in myeloid but not plasmacytoid dendritic cells. J Immunol 2007; 178:145-53.

104. Müller K, Diamant M, Bendtzen K. Inhibition of production and function of interleukin- 6 by 1,25 -dihydroxyvitamin D3. Immunol Lett 1991;28:115-20.

105. Cannell JJ, Vieth R, Umhau JC, Holick MF, Grant WB, Madronich S, et al. Epidemic influenza and vitamin D. Epidemiol Infect 2006;134:1129-40.

106. Laaksi I, Ruohola JP, Tuohimaa P, Auvinen A, Haataja $\mathrm{R}$, Pihlajamäki $\mathrm{H}$, et al. An association of serum vitamin D concentrations $<40 \mathrm{nmol} / \mathrm{l}$ with acute respiratory tract infection in young Finnish men. Am J Clin Nutr 2007;86:714-7.

107. Cannell JJ, Vieth R, Willett W, Zasloff M, Hathcock JN, White JH, et al. Cod liver oil, vitamin A toxicity, frequent respiratory infections, and the vitamin D deficiency epidemic. Ann Otol Rhinol Laryngol 2008;117:864-70.

108. Ginde AA, Mansbach JM, Camargo CA. Association between serum 25-hydroxyvitamin D level and upper respiratory tract infection in the Third National Health and Nutrition Examination Survey. Arch Intern Med 2009;169:384-90.

109. Salahuddin N, Ali F, Hasan Z, Rao N, Aqeel M, Mahmood F. Vitamin D accelerates clinical recovery from tuberculosis: results of the SUCCINCT Study [Supplementary Cholecalciferol in recovery from tuberculosis]. A randomized, placebo-controlled, clinical trial of vitamin D supplementation in patients with pulmonary tuberculosis'. BMC Infect Dis 2013;13:22.

110. Coussens AK, Wilkinson RJ, Hanifa Y, Nikolayevskyy V, Elkington PT, Islam $\mathrm{K}$, et al. Vitamin D accelerates resolution of inflammatory responses during tuberculosis treatment. Proc Natl Acad Sci USA 2012;109:15449-54.

111. Chen S, Sims GP, Chen XX, Gu YY, Chen S, Lipsky PE. Modulatory effects of 1,25-dihydroxyvitamin D3 on human B cell differentiation. J Immunol 2007;179:1634-47.

112. Mahon BD, Wittke A, Weaver V, Cantorna MT. The targets of vitamin $\mathrm{D}$ depend on the differentiation and activation status of CD4 positive T cells. J Cell Biochem 2003;89:922-32

113. Lemire JM, Adams JS, Kermani-Arab V, Bakke AC, Sakai R, Jordan SC. 1,25-Dihydroxyvitamin D3 suppresses human $\mathrm{T}$ helper/inducer lymphocyte activity in vitro. J Immunol 1985;134:3032-5.

114. Lemire JM, Adams JS, Sakai R, Jordan SC. 1a,25-dihydroxyvitamin D3 suppresses proliferation and immunoglobulin production by normal human peripheral blood mononuclear cells. J Clin Investig 1984;74:657-61.

115. Mora JR, Iwata M, von Andrian UH. Vitamin effects on the immune system: Vitamins A and D take centre stage. Nat Rev Immunol 2008;8;685-98.

116. Cantorna MT. Mechanisms underlying the effect of vitamin $D$ on the immune system. Proc Nutr Soc 2011;69:286-9.

117. Van Belle TL, Gysemans C, Mathieu C. Vitamin D in autoimmune, infectious and allergic diseases: A vital player? Best Pract Res Clin Endocrinol Metab 2011;25:617-32.

118. Palmer MT, Lee YK, Maynard CL, Oliver JR, Bikle DD, Jetten AM, et al. Lineage-specific effects of 1,25-dihydroxyvitamin D3 on the development of effector CD4 T cells. J Biol Chem 2011;286:997-1004.

119. Boonstra A, Barrat FJ, Crain C, Heath VL, Savelkoul HFJ, Garra AO. 1 $\alpha, 25$-dihydroxyvitamin D3 has a direct effect on naive CD4+T cells to enhance the development of Th2 cells. J Immunol 2001;167:4974-80.

120. Haga HJ. Vitamin D in rheumatoid arthritis. Expert Rev Clin Immunol 2013;9:591-3.

121. Sakthiswary R, Raymond AA. The clinical significance of vitamin D in systemic lupus erythematosus: a systematic review. PLoS One 2013;8:e55275.

122. Mesliniene S, Ramrattan L, Giddings S, Sheikh-Ali M. Role of vitamin D in the onset, progression, and severity of multiple sclerosis. Endocr Pract 2013;19:129-36.

123. Kamangar F, Koo J, Heller M, Lee E, Bhutani T. Oral vitamin D, still a viable treatment option for psoriasis. J Dermatolog Treat 2013;24:261-7.

124. Iijima $H$, Shinzaki S, Takehara $T$. The importance of vitamins $\mathrm{D}$ and $\mathrm{K}$ for the bone health and immune function in inflammatory bowel disease. Curr Opin Clin Nutr Metab Care 2012;15:635-40. 